\title{
Pengembangan Paket Tes Berbasis Higher Order Thinking Skills (HOTS) Pokok Bahasan Theorema Phytagoras
}

\author{
Rhema Nadya Kusuma ${ }^{1}$, Titik Sugiarti ${ }^{2}$, Lela Nur Safrida ${ }^{2}$, Susanto ${ }^{2}$, Inge Wiliandani \\ Setya Putri \\ ${ }^{1}$ Mahasiswa S1 Prodi Pendidikan Matematika FKIP Universitas Jember \\ ${ }^{2}$ Dosen Prodi Pendidikan Matematika FKIP Universitas Jember \\ E-mail: rheredijurnal@gmail.com
}

\begin{abstract}
Students' skills in answering high-order thinking skills with analysis, evaluation, and creative indicators are still in the low category. One of the efforts made to improve higher thinking skills is by using the HOTS test package. This type of research is a development research with the Thiagrajan or Four D Model which aims to describe the process and results of developing HOTS-based test packages for eighth grade students on the Theorema Pythagoras material which is valid, practical, and effective in training students' higher order thinking skills. The data collection method used the test method to determine the validity and effectiveness and the questionnaire method to determine the practicality of the test package. The results of this study are in the form of students' achievements in analyzing, evaluating, and creating in accordance with higher-order thinking indicators with good interpretations. The HOTS-based test package, the subject of Pythagorean Theorema, produced in this study is valid, practical, and effective and can be used to improve students' higher order thinking skills.
\end{abstract}

Keywords: Test Package, Pythagorean Theorem, Higher Order Thinking Skills (HOTS)

\section{PENDAHULUAN}

Menurut hasil survei yang dilakukan oleh TIMSS, kemampuan berpikir peserta didik dalam menyelesaikan suatu permasalahan secara ilmiah dianggap masih rendah. Salah satu penyebabnya adalah kurangnya paket tes yang mendukung peserta didik untuk melatih keterampilan berpikir tingkat tinggi. Pembelajaran serta instrumen disekolah kurang memfasilitasi karateristik dan keterampilan berpikir siswa [10]. Dengan pengembangan paket tes yang bisa berfungsi untuk mengukur kemampuan berpikir tingkat tinggi seperti soal model PISA sebagian besar memerlukan keterampilan untuk menyelesaikan.

Komponen paket tes terdiri atas kisi-kisi paket tes, lembar soal paket tes, kunci jawaban, dan pedoman penilian. Dalam penelitian ini soal yang digunakan adalah soal yang berbasis HOTS dengan indikator C4 (menganalisis), C5 (mengevaluasi), dan C6 (mengkreasi) [11]. Pemilihan pokok bahasan Thorema Phytagoras didasarkan pada semakin kuat pemahaman siswa terhadap konsep Theorema Phytagoras akan berbanding lurus dengan pemahaman dan penalaran dalam mempelajari konsep serta menyelesaikan permasalahan kemampuan berpikir tingkat tinggi terutama dalam bidang geometri yang lainnya. Pengembangan paket tes HOTS ini akan menghasilkan

\footnotetext{
${ }^{1}$ Mahasiswa S1 Prodi Pendidikan Matematika FKIP Universitas Jember

${ }^{2}$ Dosen Prodi Pendidikan Matematika FKIP Universitas Jember
} 
keluwesan dan kemahiran keterampilan peserta didik untuk menyelesaikan suatu permasalahan [2]. Hal tersebut dapat dilatih dengan memberikan soal latihan berbasis HOTS yang dibuat khusus sehingga peserta didik dilatih secara tidak langsung berusaha menyelesaikan permasalahan yang memancing pengembangan proses berpikir. Diharapkan prestasi dan tingkat kepercayaan diri peserta didik juga meningkat. Pengembangan paket tes HOTS perlu dilakukan untuk kemajuan peserta didik yang nantinya mereka terbiasa memecahkan permasalahan dengan kritis dan kreatif. Berdasarkan penelitian diperoleh kesimpulan bahwa masing-masing siswa memiliki kemampuan berpikir tingkat tinggi yang berbeda dalam menyelesaikan soal matematika berbasis HOTS [5]. Kemampuan tersebut dibagi menjadi 3 kategori yaitu rendah (hanya mampu memenuhi indikator analisis), sedang (hanya mampu memenuhi indikator analisis dan evaluasi), dan tinggi (mampu memenuhi indikator analisis, evaluasi, dan kreasi) [3].

Berdasarkan uraian di atas, penelitian ini dilakukan untuk mengasah kemampuan proses berpikir tingkat tinggi siswa dalam menyelesaikan soal matematika berbasis HOTS. Pemberian soal Matematika berbasis HOTS pada penelitian ini diharapkan dapat memberikan pengetahuan lebih kepada siswa mengenai permasalahan matematika yang berbeda dengan soal rutin pada umumnya. Penelitian ini memiliki rumusan masalah bagaimana proses dan hasil pengembangan paket tes HOTS Theorema Phytagoras dan penggunaanya yang valid, praktis dan efektif serta memiliki tujuan untuk mendeskripsikan suatu proses dan hasil pengembangan paket tes HOTS Theorema Phytagoras dan penggunaanya yang valid, praktis dan efektif.

\section{METODE PENELITIAN}

Jenis penelitian ini merupakan penelitian pengembangan atau biasa disebut Research \& Development. Penelitian yang memiliki orientasi untuk menghasilkan suatu produk dalam bidang pendidikan kemudian memvalidasinya disebut penelitian pengembangan [4]. Penelitian ini dilakukan di SMP Negeri 1 Cluring dikarenakan telah menerapkan pembelajaran online dengan fasilitas yang memadahi dan terdapat dua kelas unggulan. Subjek penelitian ditentukan dengan teknik random sampling dan dipilih siswa kelas 8C yang termasuk kelas unggulan dengan terdapat siswa dengan kemampuan rata-rata tinggi dan sedang sebagai subjeknya. Tahapan pengembangan paket tes ini terdiri atas empat tahap yaitu pendefinisian (define), tahap perancangan (design), tahap pengembangan (develop), dan tahap penyebaran (dessiminate) yang dikenal dengan Four-D Model [9]. Pemilihan model ini dikarenakan pengembangan dengan menggunakan Four-D Model lebih sistematis serta sebelum uji coba dilakukan harus melewati penilaian oleh dua orang yang berkompeten untuk memvalidasi produk yang dihasilkan.

Dalam penelitian ini apabila instrumen minimal telah mencapai kategori cukup valid ataupun valid, maka instrumen dapat digunakan. Apabila instrumen belum valid ataupun masih terdapat beberapa revisi pada bagian tertentu maka dilakukan revisi hingga instrumen mencapai kategori cukup valid ataupun valid. Sebelum melakukan pengumpulan data, dilakukan validasi instrumen, terutama validasi mengenai paket tes oleh validator dengan menghitung nilai $V_{a}$, kemudian menghitung rerata total pada semua aspek hingga memperoleh kategori kevalidan yang sesuai dengan tabel 1 . 
Tabel 1. Kategori Validitas Instrumen

\begin{tabular}{cc}
\hline Nilai $\boldsymbol{V}_{\boldsymbol{a}}$ & Kategori Kevalidan \\
\hline $1 \leq V_{a}<2$ & Tidak Valid \\
$2 \leq V_{a}<3$ & Cukup Valid \\
$3 \leq V_{a}<4$ & Valid \\
$V_{a}=4$ & Sangat Valid \\
\hline
\end{tabular}

Kepraktisan paket tes HOTS adalah data yang menggambarkan keterlaksanaan paket tes tersebut. Data kepraktisan dalam penelitian ini diukur dengan meggunakan hasil angket respon siswa dan guru. Data respon guru dan siswa yang diperoleh melalui angket yang dianalisis berdasarkan persentase. Respon dikatakan baik apabila $\geq 75 \%$ siswa dan guru merespon dengan memilih jawaban "Setuju" atau "Ya" untuk setiap indikator. Keefektifan paket tes ditentukan dari ketuntasan hasil tes siswa berdasarkan setiap indikator kemampuan berpikir tingkat tinggi.

Pada penelitian ini, skor yang didapatkan peserta didik setelah mengerjakan soal tes dihitung persentasenya untuk mengukur kemampuan berpikir tingkat tinggi dan dikategorikan dalam kategori yang sesuai dengan tabel 1. Nilai minimal efektifitas dari hasil tes kemampuan berpikir tingkat tinggi siswa adalah $60 \%$ dari hasil skor siswa yang berada pada interval $65 \leq$ nilai $<85$ dengan kategori baik.

Tabel 2. Kategori Tingkat Kemampuan Berpikir Tingkat Tinggi Nilai Siswa Tingkat Kemampuan Berpikir

\begin{tabular}{cc} 
Nilai Siswa & Tingkat Tinggi \\
\hline $85 \leq$ nilai $\leq 100$ & Sangat Baik \\
$65 \leq$ nilai $<85$ & Baik \\
$45 \leq$ nilai $<65$ & Cukup \\
$25 \leq$ nilai $<45$ & Kurang \\
$0 \leq$ nilai $<25$ & Sangat Kurang \\
\hline
\end{tabular}

Keefektifan paket tes diukur dengan menganalisis skor atau hasil yang didasarkan pada kategori kemampuan berpikir tingkat tinggi. Paket tes yang dihasilkan dikatakan efektif apabila persentasi minimal $70 \%$ dari hasil tes atau skor yang diperoleh siswa memenuhi kriteria kemampuan berpikir tingkat tinggi minimal baik.

\section{HASIL DAN PEMBAHASAN}

Pengembangan dengan model Thiagarajan memiliki empat tahap yaitu pendefinisian, perancangan, pengembangan serta penyebaran. Terdapat empat langkah pokok dalam tahap pendefinisian (define) yaitu analisis awal - akhir, analisis siswa, analisis materi, dan spesifikasi tujuan. Analisis awal - akhir dilakukan wawancara yang berkaitan dengan kondisi siswa serta metode pembelajaran kepada Ibu Kun Erni, S.Pd. selaku guru matematika di sekolah. Analisis siswa digunakan untuk menggali informasi tentang kemampuan matematika siswa dan diperoleh informasi bahwa kemampuan siswa dalam menemukan konsep serta mengintegrasikan konsep pada sebuah masalah masih kurang. Informasi lain yang diperoleh adalah soal yang diberikan ke siswa umumnya berisikan soal-soal biasa yang belum berbasis Higher Order Thinking Skills (HOTS). KI dan KD diperlukan untuk merumuskan spesifikasi tujuan pembelajaran pada materi Theorema Phytagoras.

Terdapat empat langkah utama dalam tahap design yaitu penyusunan tes, pemilihan media, pemilihan format serta rancangan awal. Penyusunan tes terdiri atas 10 
buah soal uraian untuk mengukur kemampuan berpikir tingkat tinggi siswa. Berdasarkan hasil penelitian relevan dikemukakan bahwa untuk mengukur perubahan tingkah laku siswa setelah kegiatan pembelajaran dapat dilakukan dengan penyusunan tes [9]. Dalam penelitian ini dipilih paket tes HOTS sebagai media yang digunkan dalam pembelajaran. Pemilihan format paket tes yang dikembangkan adalah paket tes yang berbabasis Higher Order Thinking Skills (HOTS) yang membantu siswa untuk mengasah kemampuan berpikir tingkat tinggi dengan menganalisis, mengevaluasi, mengkreasi, menemukan konsep, menerapkan dan mengintegrasikan berbagai konsep yang telah ada. Perancangan awal dalam tahap ini harus disesuaikan dengan format paket tes yang akan dikembangkan. Hal tersebut sejalan dengan penelitian yang menyatakan bahwa tahap perancangan (design) meliputi penyusunan tes hasil belajar pada pokok bahasan yang diharapkan, memilih media yang tepat yaitu dengan menggunakan paket tes dan terakhir merancang perangkat untuk diujicobakan [7].

Kegiatan selanjutnya dalam tahap develop adalah penilaian para ahli dan uji coba produk. Penelitian relevan lain mengemukakan bahwa pada tahap pengembangan dilakukan validasi ahli terhadap LKS yang dikembangkan, kemudian dilakukan uji coba pada 20 siswa kelas VII SMP Islam Al-Ikhlasyiah [1]. Penilaian para ahli dilakukan oleh validator yang berkompeten untuk memberikan penilaian terhadap LKS serta beberapa instrumen penelitian lainnya. Penilaian para ahli dilakukan dengan menyerahkan instrumen penelitian beserta lembar validasi kepada validator. Pada tabel 3. dipaparkan perhitungan validasi paket tes sebagai berikut.

Tabel 3. Perhitungan Validasi Paket Tes

\begin{tabular}{|c|c|c|c|c|c|c|}
\hline No. & $\begin{array}{c}\text { Aspek } \\
\text { Validasi }\end{array}$ & Aspek yang divalidasi & $\begin{array}{c}\text { Validator } \\
1\end{array}$ & $\begin{array}{c}\text { Validator } \\
2\end{array}$ & $\boldsymbol{I}_{\boldsymbol{i}}$ & $V_{a}$ \\
\hline 1. & $\begin{array}{l}\text { Validasi } \\
\text { Petunjuk } \\
\text { Pengerjaan }\end{array}$ & $\begin{array}{l}\text { Kejelasan dan kesesuaian } \\
\text { petunjuk pengerjaan soal tes }\end{array}$ & 3 & 4 & 3,5 & \multirow{9}{*}{3,44} \\
\hline 2. & Validasi Isi & $\begin{array}{c}\text { Soal sesuai dengan materi } \\
\text { Theorema Phytagoras }\end{array}$ & 4 & 3 & 3,5 & \\
\hline \multirow{3}{*}{3.} & \multirow{3}{*}{$\begin{array}{l}\text { Validasi } \\
\text { Bahasa }\end{array}$} & $\begin{array}{l}\text { Bahasa Indonesia yang } \\
\text { digunakan baik dan benar }\end{array}$ & 3 & 4 & 3,5 & \\
\hline & & Bahasa bersifat komunikatif & 3 & 4 & 3,5 & \\
\hline & & $\begin{array}{l}\text { Kalimat dalam soal tes } \\
\text { mudah dipahami dan tidak } \\
\text { menafsirkan makna ganda }\end{array}$ & 2 & 3 & 2,5 & \\
\hline \multirow{4}{*}{4.} & \multirow{4}{*}{$\begin{array}{l}\text { Validasi } \\
\text { Konstruk }\end{array}$} & $\begin{array}{c}\text { Soal tes yang disajikan } \\
\text { mengakomodasi kriteria soal } \\
\text { HOTS }\end{array}$ & 4 & 4 & 4 & \\
\hline & & $\begin{array}{c}\text { Soal tes yang disajikan } \\
\text { mengakomodasi aspek } \\
\text { analisis }\end{array}$ & 4 & 3 & 3,5 & \\
\hline & & $\begin{array}{c}\text { Soal tes yang disajikan } \\
\text { mengakomodasi aspek } \\
\text { evaluasi }\end{array}$ & 4 & 3 & 3,5 & \\
\hline & & $\begin{array}{c}\text { Soal tes yang disajikan } \\
\text { mengakomodasi aspek } \\
\text { mengkreasi }\end{array}$ & 3 & 4 & 3,5 & \\
\hline
\end{tabular}


Berdasarkan tabel 4, maka didapatkan nilai rata-rata total dari kedua validator adalah 3,44 dan berada pada interval $3 \leq V_{a}<4$. Kriteria validitas pada soal tes HOTS dinyatakan valid.

Tahap develop dibagi menjadi dua uji yaitu uji terbatas dengan 7 siswa yang berguna untuk mengetahui validitas, daya pemberda, dan reliabilitas paket tes dan uji lapangan yang bertujuan untuk mengetahui kepraktisan dan keefektifan paket tes. Pada tahap develop dihasilkan paket tes dengan kategori sangat valid dengan uji daya pembeda dikatakan baik dan layak digunakan apabila soal tersebut memiliki daya pembeda antara 0,19-1 dan tingkat reliabilitas menghasilkan nilai Cronbach's Alpha sebesar 0.860 dengan 10 item dan dinyatakan reliabel sehingga kemudian dilakukan uji lapangan kepada 30 siswa yang digunakan untuk menganalisis keefektifan dan kepraktisan paket tes [1].

Hasil pengumpulan data yang didapat melalui uji coba dianalisis tingkat kepraktisan dan keefektifan. Data kepraktisan diperoleh dengan menganalisis data hasil angket respon guru dan siswa yang dilakukan satu kali pada pertemuan secara online. Berdasarkan perhitungan analisis data hasil kepraktisan paket tes dari angket respon guru diperoleh kategori sangat baik dengan rincian data sebesar 90,90\% dengan data mengenai hasil angket respon guru tertera pada Gambar 1. Penelitian ini sejalan dengan penelitian terdahulu yang mengemukakan bahwa data hasil angket respon guru dan siswa digunakan untuk menganalisis kepraktisan paket tes, di mana dalam penelitian tersebut dilakukan untuk mengembangkan perangkat pembelajaran berbasis problem solving dan diperoleh persentase angket respon guru sebesar $92,50 \%$ yang memenuhi kriteria sangat baik [8].

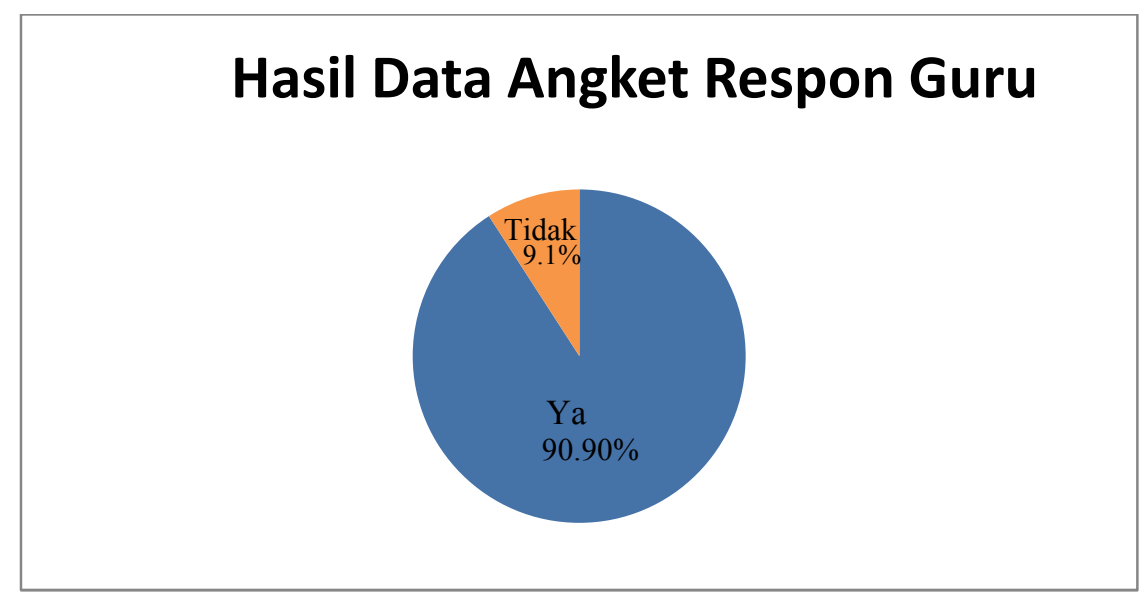

Gambar 1. Hasil Data Angket Respon Guru

Hasil analisis data angket respon siswa diperoleh skor yang berada pada interval $85 \% \leq x \leq 100 \%$ dengan skor total observer 30 siswa dan pernyataan dalam angket berjumlah tujuh item yang tertera pada Gambar 2. Dari analisis data tersebut paket tes HOTS Theorema Phytagoras dapat dikatakan praktis. 


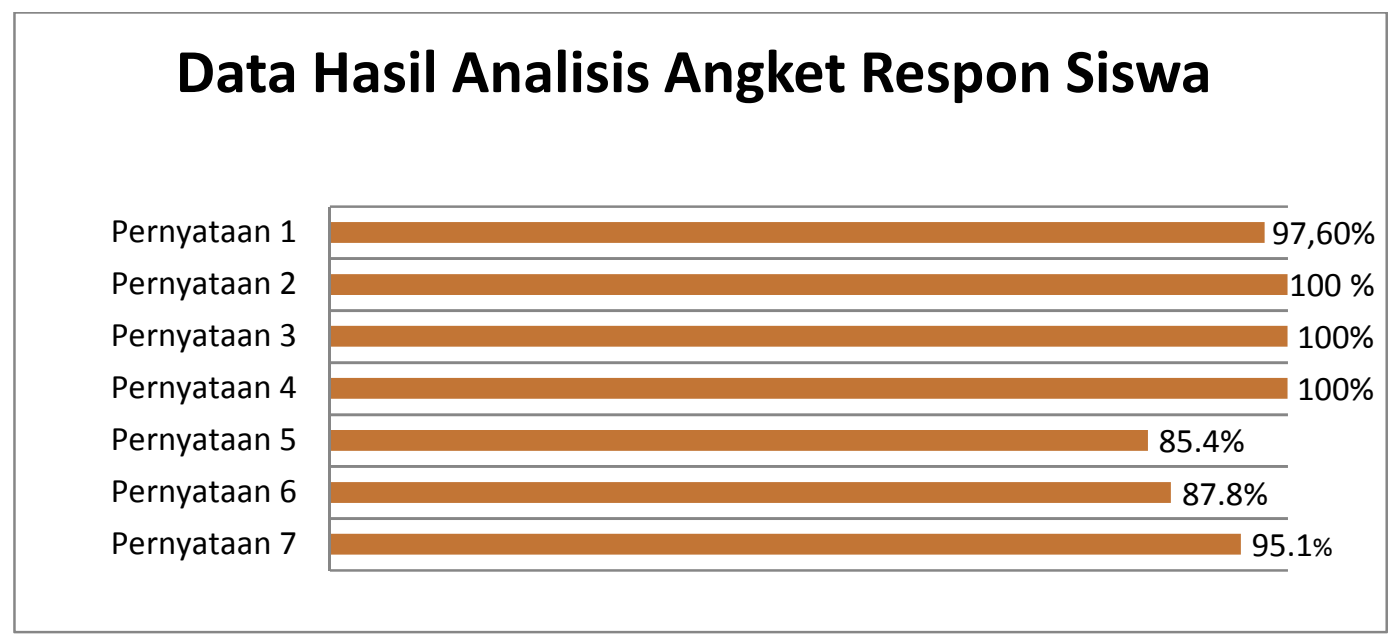

Gambar 2. Data Hasil Angket Respon Siswa

Indikator mencakup data hasil skor akhir tes yang digunakan untuk menganalisis keefektifan dari suatu perangkat pembelajaran [6]. Perhitungan analisis data hasil tes di kelas 8C dengan 30 siswa diperoleh keseluruhan siswa telah tuntas. Data hasil tes dipaparkan pada Gambar 3.

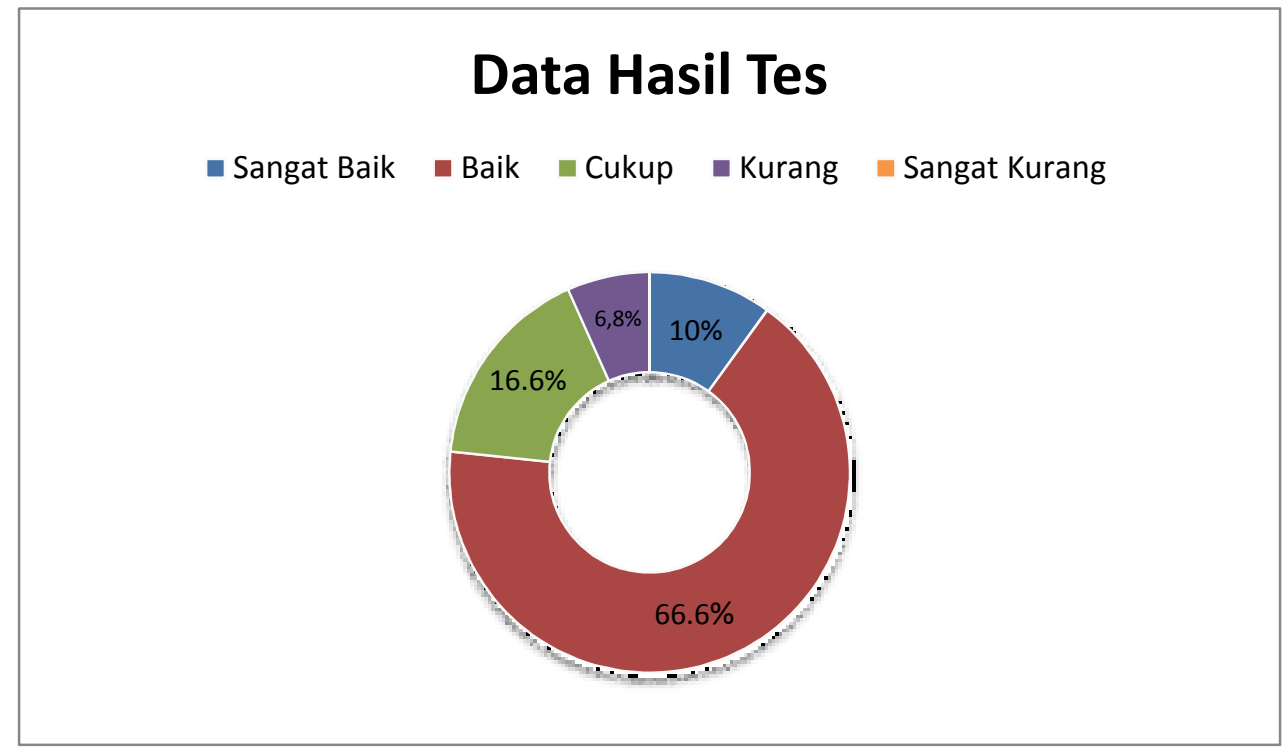

Gambar 3. Data Hasil Tes

Keefektifan paket tes diukur dengan menganalisis skor atau hasil kemampuan berpikir tingkat tinggi yang didapatkan peserta didik setelah mengerjakan soal tes dan diolah dengan cara dihitung persentasenya. Skor akhir diolah sehingga menghasilkan nilai akhir yang dikonversikan ke kategori kemampuan berpikir tingkat tinggi. Berdasarkan data hasil uji terbatas dan uji lapangan diketahui bahwa secara keseluruhan dari 30 siswa kelas VIII SMP N 1 Cluring yang memiliki kemampuan berpikir tingkat tinggi dengan kategori sangat baik berjumlah 3 siswa (10\%), kategori baik berjumlah 20 siswa (66,6\%), kategori cukup berjumlah 5 (16,6\%), kategori kurang berjumlah 2 siswa $(6,8 \%)$ dan tidak ada siswa dengan kategori sangat kurang. Jadi dapat disimpulkan bahwa paket tes memenuhi kriteria efektif dengan kategori minimal baik $(76,6 \%)$ dan dapat dikembangkan sesuai dengan tujuan yang diharapkan. Berdasarkan keseluruhan 
hasil analisis data dalam penelitian ini diperoleh kesimpulan bahwa paket tes berbasis Higher Order thinking Skills (HOTS) pokok bahasan Theorema Phytagoras dapat dikatakan valid, praktis dan efektif.

Tahap terakhir dalam Four-D Model adalah penyebaran (disseminate) yang bertujuan untuk menyebarluaskan produk pengembangan yang dihasilkan [7]. Dalam penelitian ini dilakukan penyebarluasan paket tes di SMP Negeri 1 Cluring melalui guru matematika dan penyebaran online melalui social media dengan cara mengunggah link Google Drive yang berisikan paket tes yang telah dikembangkan.

\section{KESIMPULAN}

Paket tes yang dikembangkan telah memenuhi karateristik langkah berpikir tingkat tinggi materi Theorema Phytagoras yang terdiri dari (1) pendefinisian (define), (2) perancangan (design), (3) pengembangan (develop), dan (4) pengembagan (dessiminate). Berdasarkan hasil analisis kevalidan, kepraktisan, dan keefektifan paket tes, dapat disimpulkan bahwa paket tes berbasis Higher Order thinking Skills (HOTS) pokok bahasan Theorema Phytagoras dapat dikatakan valid, praktis dan efektif dan layak digunakan sebagai alternatif bahan ajar untuk siswa SMP kelas VIII agar dapat mengasah kemampuan berpikir tingkat tinggi khususnya materi Theorema Phytagoras. Adapun kebaruannya terletak pada pengoptimalan pengembangan paket tes yang terstruktur dan memadukan jenis paket tes biasa dengan paket tes berbasis HOTS dengan maksud untuk mengasah kemampuan berpikir tingkat tinggi siswa. Peneliti memberikan saran kepada peneliti selanjutnya untuk dapat mengembangkan produk berupa paket tes HOTS pada materi lainnya dan perlunya dilakukan secara rutin agar memberikan hasil yang lebih memuaskan.

\section{DAFTAR PUSTAKA}

[1] Arief, M. M., Ainy , C., \& Suryaningtyas, W. (2016). Pengembangan Lembar Kerja Siswa (LKS) Matematika Materi Prisma Kelas VIII dengan Pendekatan Scientific di SMP DR.Soetomo Surabaya. Journal of Mathematics Education, Science and Technology, 1(2), 209-221.

[2] Aryani, I. dan Maulida. 2019. Analisis Kesalahan Siswa Dalam Menyelesaikan Soal Matematika Melalui Higher Order Thinking Skills (HOTS). Jurnal Serambi Ilmu: Journal of Scientific Information and Educational Creativity. Volume 20(2), pp. 277-290.

[3] Hasyim Adelina, 2016. Metode Penelitian Dan Pengembangan Di Sekolah. Yogyakarta : Media Akademi.

[4] Hermawan, I. (2019). Metodologi Penelitian Pendidikan Kuantitatif, Kualitatif dan Mixed Methode. Karawang: Hidayatul Quran.

[5] Kurniati, Dian., Harimukti, Romi., \& Jamil, Nur Aisyah. (2016). Kemampuan berpikir tingkat tinggi siswa SMP di kabupaten Jember dalam menyelesaikan soal berstandar PISA. Jurnal Penelitian dan Evaluasi Pendidikan, 20(2), 142-155.

[6] Murtikusuma, R. P., Hobri, Fatahillah, A., Husen, S., Prasetyo , R. R., \& Alfarisi, M. A. (2019). Development of Blended Learning Based on Google Classroom with Using Culture Theme in Mathematics Learning. IOP Conf. Series: Journal of Physics:, 1165(01), 1-8.

[7] Saadah, L. Z. (2018). Pengembangan Perangkat Pembelajaran Problem Based Learning Berbasis Lesson Study For Learning Community (LSLC) Pada Bahasan 
Bangun Ruang Sisi Datar Untuk Meningkatkan Berfikir Kreatif Siswa. Skripsi. Jember : Universitas Jember.

[8] Safrida, Lela Nur. 2016. Pengembangan Perangkat Pembelajran Berbasis Problem Solving Polya Untuk Meningkatkan Kemampuan Penalaran Matematis Siswa Materi Peluang Kelas XI SMA. Malang: Univeritas Negeri Malang.

[9] Sutarti, T., \& Irawan, E. (2017). Kiat Sukses Meraih Hibah Penelitian Pengembangan. Yogyakarta: Deepublish.

[10] Sugiarti, Titik. (2013). Pengembangan Model Pembelajaran Matematika Berbasis Authentic Assesment Melalui Exemplar Problem untuk Meningktkan Kemampuan Pemecahan Masalah Siswa Sekolah Dasar. Jember: Universitas Jember.

[11] Widana, I Wayan. (2012). Modul: Penyusunan Soal Higher Order Thinking Skills. Jakarta: Direktorat Pembinaan SMA, Direktorat Jendral Pendidikan Dasar dan Menengah dan Departemen Pendidikan dan Kebudayaan. Diakses melalui http://bit.ly/2ikfljh pada tanggal 18 Oktober 2020 pukul 13.04 WIB. 